Sallay Hedvig*

\title{
SERDÜLŐK SZUBJEKTÍV JÓLLÉTE: A CSALÁDBAN ÉS A BARÁTI KAPCSOLATBAN ÉSZLELT IGAZSÁGOSSÁG ÉS AZ IGAZSÁGOS VILÁGBA VETETT HIT SZEREPE
}

\begin{abstract}
Melvin Lerner nevéhez fúződik az „igazságos világba vetett hit” hipotézise, melynek értelmében az emberek úgy vélik, hogy rendszerint mindenki azt kapja életében, amit megérdemel, illetve azt érdemli meg, amit kap. Számos korábbi vizsgálat igazolta, hogy ez a motívum szorosan összefügg a mentális egészséggel: általában minél erôsebben él bennünk ez a nézet, annál inkább motiváltak vagyunk védelmére, s teszünk meg mindent annak érdekében, hogy szükség esetén az adaptív coping mechanizmusok múködésbe lépjenek.

Ez a tanulmány serdülők szubjektív jóllétét vizsgálja abból a szempontból, hogy az igazságosság motívum, valamint a családban és a baráti kapcsolatban megtapasztalt igazságosság milyen módon és mértékben játszik szerepet a serdülók mentális egészségének biztosításában. A szubjektív jóllét különbözó komponenseit elemezve (élettel szembeni pozitív attitúd; személyes problémák; szomatikus tünetek és reakciók; önértékelés; depresszív hangulat; az élet örömei) az eredmények egyértelmúen azt mutatták, hogy a különféle szocializációs közegekben átélt igazságosság és az igazságosság motívum jelentôs hatótényezóket képviselnek a serdülók mentális egészségének biztosításában.
\end{abstract}

Kulcsszavak: serdülőkor, igazságosság motívum, szubjektív jóllét, szocializációs közegek.

\section{BEVEZETÓ}

\section{Az igazságos világba vetett hit}

Az emberek sokszor különböznek egymástól abban, hogy bizonyos szituációkat méltányosnak vagy méltánytalannak tartanak-e, s ez hatással lesz arra nézve, hogy mennyire könnyen fognak megbirkózni az adott szituációval. Az igazságosság magyarázatára a pszichológiában kétféle megközelítés ismert: az egyik tartalomorientált, a másik pedig motivációra irányuló (Dalbert, 2001). A tartalomorientált megközelítés azzal a kérdéssel kezdődik, hogy mi az, amit méltányosnak/igazságosnak, illetve méltánytalannak/igazságtalannak látunk. A kutatók ezen a téren már leír-

\footnotetext{
* Dr. Sallay Hedvig

Debreceni Egyetem, Pszichológia Intézet

4010 Debrecen 10, Pf. 28

E-mail: hsallay@delfin.unideb.hu
} 
ták a disztributív és procedurális igazságosság szabályait, és azonosították azokat a szituációs feltételeket és személyiségjellemzóket is, melyek e speciális szabályok alkalmazásához vezetnek. A motivációs megközelítés arra vonatkozik, hogy az emberek miért foglalkoznak az igazságosság kérdésével, milyen erős bennük az igazság iránti vágy, s ez a motívum hogyan irányítja a viselkedésüket, cselekvéseiket. E megközelítés értelmében az igazságosság egy szubjektív konstruktum. Azok a kutatások, melyek ezt a szempontot érvényesítik, megmutatják, hogy az igazságosság az élet minden területén fontos szerepet játszik - pl. akkor, ha a személyek átélt vagy megfigyelt igazságtalanságra reagálnak.

A nyugati társadalmakban az igazságra való törekvés olyan átható erővel rendelkezik, hogy képesek az emberek szabadságukat, életüket és boldogságukat is feláldozni érte. Felmerül ezért az a kérdés, hogy mi miatt fontos ennyire az igazság az emberek számára?

A pszichológusok megpróbáltak erre kielégítő választ adni. Tény, hogy az emberekben nagyon erős az igazság iránti vágy: szeretnének egy olyan világban élni, ahol mindenki méltányos bánásmódban részesül. Tulajdonképpen a fenti gondolatmenet vezette el Melvin Lerner-t az „igazságos világba vetett hit" hipotézisének megfogalmazásához.

Lerner (1998) szerint az emberek kétféle moralitással élnek. Az egyik tudatosan hozzáférhetó, s ez tartalmazza mindazt, amit a megfeleló szituációkban „tennünk kell”: ezek normákon alapuló kötelességek, melyeket a racionális önérdek szempontjából alkalmazunk. Vannak azonban emellett morális intuícióink is, melyek automatikusan sugalmazzák számunkra azt, hogy mi az, ami helyes, és mi az, ami nem. Hogy az adott helyzetben miképpen cselekszünk, s melyik moralitás kerül előtérbe, azt olyan tényezôk határozzák meg, mint a kiváltó esemény jelentôsége abból a szempontból, hogy igazságtalanság élményen alapuló érzelmeket (düh, szomorúság) kivált-e, s hogy vannak-e jelen normatív korlátozások, melyek megkívánják a személytől, hogy döntését átgondolja. Tehát az igazságosság motívum általános elmélete magában foglalja azt a kötelességet, hogy jó állampolgárok, szülook, vezetôk stb. legyünk, amikor ez a személyesen leginkább kifizetődô út. Emellett persze úgy gondoljuk, hogy tudatában vagyunk annak, hogy ez egyfajta szenzitív viselkedés, de ha bármi kihívást jelent a morális intuícióinkra nézve, viselkedésünk tükrözni fogja a világ megkonstruálásának követelményeit, vagyis az igazságosság motívummal összhangban fogunk cselekedni és reagálni (Lerner 1987). Az igazságos világba vetett hit mindenkinél egyénileg fejlódik ki, de a társadalomnak köszönhetôen éri el azt a hatást, ami tulajdonképpen fenntartja. A szociális interakciók és kapcsolatok örvényében rejlik a lényege.

Miért tekinthetó az igazságos világba vetett hit az igazságosság motí- 
vum jelzésének? Dalbert (2001) érvelése szerint maga az igazságosság motívum többet takar, mint az igazságtalanság egyszerú tagadása: magában foglalja azt, hogy a megfigyelók - akik valamilyen méltánytalanságot észlelnek - törekednek az áldozat kompenzálására, arra, hogy az áldozatokat arra biztassák, hogy követeljék a nekik kijáró kompenzációt, s ezen túl ók maguk pedig úgy viselkedjenek, hogy az igazsággal összefüggó normákat tartsák szem elótt. A szerzô számos olyan vizsgálatot sorol fel, melyek mind egyértelmúen igazolják azt, hogy az igazságos világba vetett hitet méró skálákkal végzett kutatások teljesítik ezeket a kritériumokat.

Az is könnyen belátható, hogy miért „implicit” ez a motívum. Az alkalmazott kérdőívek állításai a személyes, individuális világról kialakított nézeteket mérik be, igazságossághoz kapcsolódó állítások segítségével. A kutatások számottevó bizonyítékkal szolgálnak arra nézve, hogy az igazságos világba vetett hit úgy múködik, mint egy implicit motívum (Furnham és Proctor 1989).

Az implicit igazságosság motívummal foglalkozó kutatások ennek a motívumnak három fó funkciójára mutattak rá (Dalbert 2001):

1) jelzik azt a személyes szerzódést, melyben kötelességünknek érezzük, hogy másokkal szemben méltányosan viselkedjünk;

2) megadja azt a bizonyosságérzést, hogy mások is méltányosan fognak velünk viselkedni, s nem fogunk áldozatául esni elóre nem látható kellemetlen eseményeknek;

3) olyan konceptuális keretet kínál, melynek segítségével a személyek saját, és mások életének eseményeit értelemmel ruházhatják fel.

Az igazságos világba vetett hitnek ezek a sajátosságai lefedik az igazságosság motívum teljes egészét, s emellett az emberi viselkedés széles körére is magyarázatot kínálnak.

Az igazságos világba vetett hit egyénileg változó diszpozíció (Rubin és Peplau 1973), ami skálákkal (igazságos világ skálákkal) mérhetô (pl. Dalbert és mtsai 1987). A legutóbbi kutatások azt mutatták, hogy az általános igazságos világba vetett hit megkülönböztethetô a személyes igazságos világba vetett hittól (Lipkus és mtsai 1996). Az általános igazságos világba vetett hit kifejezi azt a nézetet, hogy általában véve a világ egy igazságos hely, a személyes igazságos világba vetett hit pedig azt hangsúlyozza, hogy az egyén saját sorsa igazságos, és életének eseményeit megérdemli. Az általános és személyes igazságos világba vetett hit közös varianciával tükrözi vissza, hogy a világ értelemmel rendelkezik.

Az igazságossággal kapcsolatos nézetek fokozatosan fejlődnek ki, s a családban és a baráti kapcsolatokban szerzett személyes tapasztalatok fontos szerepet töltenek be ebben a folyamatban (Sallay 2005). 


\section{Az igazságos világba vetett hit és a mentális egészség kapcsolata}

Dalbert (2001) szerint az igazságos világba vetett hit és a mentális egészség között két különbözó indirekt összefüggés írható le. Az egyik a hétköznapi életben érvényes: ilyenkor az igazságos világba vetett hit egy stabil személyes diszpozícióként értelmezhetó, ami tükrözi, hogy saját cselekvéseinkben az igazságosságra törekszünk, de emellett bízunk abban is, hogy mások is hasonlóképpen fognak velük szemben viselkedni. Ez az igazságosságba vetett bizalom egyfajta ütközó (buffer) szerepét töltve be a mentális egészség megớrzését szolgálja. A másik összefüggés, ami az elózótól kissé eltér, a kritikus életesemények áldozataira érvényes. Az igazságos világba vetett hit alapvetó funkcióival együtt jár, hogy bármikor, amikor valami veszély fenyegeti az igazságos világba vetett hitet, az egyének erősen motiváltak lesznek arra, hogy ezt a hitüket megvédjék. Az igazságos világba vetett hit így veszélybe kerülhet minden olyan esetben, amikor méltánytalansággal, igazságtalansággal szembesülünk - s ilyen helyzetet képviselhetnek olyan kritikus életesemények, mint pl. a munkanélkülivé válás, a sérült gyermek születése is. Azonban minél erősebb az igazságos világba vetett hit, annál erősebben motiváltak vagyunk e hit védelmére, s teszünk meg mindent annak érdekében, hogy az adaptív coping-reakciók múködésbe lépjenek. Az igazságos világba vetett hit tehát az ütközó szerepét tölti be mind a hétköznapi életben, mind a kritikus élethelyzetekben, amikor valaki a sors áldozatává válik csak az igazságos világba vetett hit és mentális egészség közötti összefüggést más és más tényezók közvetítik és moderálják a két esetben.

A szakirodalom ennek megfelelóen megkülönbözteti azokat a vizsgálatokat, melyekben kritikus élethelyzetekbe került áldozatok, illetve a hétköznapi események szereplói vesznek részt. Ez utóbbi csoportba tartozó kutatások száma viszonylag kevés. Schmitt és Maes (2000) szignifikáns negatív kapcsolatot találtak a depresszió és az általános igazságos világba vetett hit között egy 2500 fóból álló német mintán. Lipkus és mtsai (1996) vizsgálatában azok az egyetemisták, akik erósen hittek az igazságos világban, kevesebb depresszív tünetet mutattak, és életükkel elégedettebbek voltak, mint azok, akik kevésbé hittek az igazságos világban. Burke (1985) az A-típusú viselkedéssel való összefüggést kimutatva azt az eredményt kapta, hogy az A-típusú viselkedés fóként olyan személyekre volt jellemzó, akik hosszú távon kevéssé hittek az igazságos világban.

Kritikus életeseményeket átélt személyekkel jóval több vizsgálat folyt. Lerner és Somers (1992) munkanélkülivé vált egyénekkel végeztek kér- 
dóíves felmérést, s két pozitív összefüggésre hívták fel a figyelmet, a szubjektív jóllét és a személyes nézetek, valamint a szubjektív jóllét és igazságos világba vetett hit tekintetében. Azok a munkanélkülivé vált dolgozók, akik határozottabban hittek az igazságos világban, szubjektíven sokkal kellemesebben érezték magukat. Meg kell azonban jegyeznünk, hogy vannak olyan vizsgálatok is a szakirodalomban, melyek vegyes, vagy éppen a kapcsolat hiányát bizonyító eredményeket mutatnak (l. Agrawal és Dalal 1993; Kiecolt-Glaser és Williams 1987). Amikor viszont olyan kutatásokat terveztek, ahol közvetlen összehasonlítás történt a hétköznapi, illetve kritikus eseményt átélt személyek igazságos világba vetett hite és szubjektív jóllét között, egyértelmúen kitúnt, hogy a szoros kapcsolat elsósorban az áldozatok esetében volt kimutatható (pl. Benson és Ritter 1990). Ez érthetó, hiszen az áldozatok azok, akiknek szüksége volt egy olyan mentális eróforrásra, mint az igazságos világba vetett hit, annak érdekében, hogy megórizzék, vagy fenntartsák szubjektív jóllétüket. Emellett az sem közömbös, hogy az igazságos világba vetett hit mérése milyen eljárással történik. Dalbert (2001) utalt arra, hogy a személyes igazságos világba vetett hit - az általános igazságos világba vetett hittel szemben - sokkal erősebben korrelál a szubjektív jólléttel.

A következókben egy olyan vizsgálatot fogunk részletesen ismertetni, amely az igazságos világba vetett hit szerepét mutatja be a szubjektív jóllét alakulásában serdülók esetében. E vizsgálat sajátossága, hogy az igazságos világba vetett hit mellett más tényezők szerepét is firtatja a szubjektív jóllétre gyakorolt hatásokat illetóen, pontosabban a közeli kapcsolatokban - családban és barátságokban - tapasztalt igazságosság szerepére hívja fel a figyelmet. Először azonban tekintsük át, hogy mi jellemző a serdülók szubjektív jóllétére.

\section{A serdülókori szubjektív jóllét}

Az elmúlt évtizedekben a fiatalokkal, serdülókkel foglalkozó vizsgálatok fóként a pszichés distresszre (normaszegó viselkedésre, táplálkozási rendellenességekre, depresszióra stb.) koncentrálódtak, ami a fiatalkorú népességnek csupán kisebb hányadát érinti. Szükségessé vált ezért az általános, hétköznapi élet egy olyan indexét bevezetni, ami minden egyénre egyformán érvényes és mérhetó - ez pedig a szubjektív jóllét. Grob (1998) szerint a szubjektív jóllét jelentósége abban rejlik, hogy alapvetóen befolyásolja mindennapi életünket, emellett a pszichés egészség globális indikátora is egyben (Taylor és Brown 1988). Motivációs összetevóje révén 
mindannyian arra törekszünk, hogy a kellemes állapotokat, jó hangulatot fenntartsuk, a kellemetlen állapotokat pedig minél hamarabb megszüntessük.

A szubjektív jóllétnek két komponensét tartja nyilván a szakirodalom (Diener 1984; Grob 1995). Az egyik a kognitív tapasztalatokat foglalja magában, utalva arra, hogy az emberek aktuális helyzetüket összehasonlítják a vágyott vagy elérni kívánt állapottal, az ideálisnak tartottal. Ha a kettó közötti eltérés nulla vagy pozitív, a személy elégedettnek fogja tartani magát (Cantril 1965). A másik az affektív folyamatokat helyezi elôtérbe (Bradburn 1969), mivel életünk eseményeit emocionálisan is értékeljük. Ha együttesen vesszük figyelembe a kognitív és affektív folyamatokat, több olyan komponenst is leírhatunk, ami a szubjektív jóllét szempontjából releváns. Ebben a vizsgálatban Grob (1995) konceptualizálását fogjuk követni, aki a szubjektív jóllétet az élettel szembeni pozitív attitúdökben, a személyes problémák, depresszív hangulat és szomatikus panaszok hiányában, valamint a magas önértékelésben és az élet örömeinek élvezetében fogalmazta meg.

Több olyan vizsgálat is napvilágot látott, mely kiemelte a serdülókori szubjektív jóllét fontosságát. A serdülókor ugyanis fejlődéslélektani szempontból olyan periódusnak tekinthetó, melynek során a család fontossága valamelyest csökken, de elótérbe kerülnek a családon kívüli interakciók és személyes életcélok (Fend 1990). Azt, hogy a serdüló miképp érzi magát a világban, szubjektív jólléte hogyan alakul, több tényezó is befolyásolhatja. A társadalmi-gazdasági helyzet hatását Grob és mtsai (1996) demonstrálták 14 európai országot magában foglaló felmérésükben. Eredményeik azt mutatták, hogy a nyugati országokban élő serdülók önértékelése magasabb, élettel szembeni attitúdje pozitívabb, mint a volt szocialista országokban élő serdülóké. Ennek hátterében a szerzók az eltéró gazdasági feltételeket vélték megtalálni, amit más, korábbi vizsgálat is igazolt (Diener és Diener 1995). Középiskolásokkal végzett felmérésükben Katja és mtsai (2002) azt az eredményt kapták, miszerint lányoknál az általános szubjektív jóllétet az iskolával és a testképpel való elégedettség, valamint a jó egészségi állapot befolyásolta. A fiúk esetében a legfontosabb tényezónek a viszonylag kevés alkoholfogyasztás tûnt, ami a teljes variancia $31 \%$-át magyarázta. Szintén az iskolai kontextus szerepét erósítette meg a szubjektív jóllét alakulásában Konu és mtsai vizsgálata (2002).

A szubjektív jólléttel foglalkozó irodalom ugyanakkor viszonylag kevés figyelmet szentel a közeli kapcsolatoknak, s e kapcsolatokban megtapasztalt személyes bánásmódnak, méltányosságnak. Lane (2000) kiemeli az emberi fejlődés, szubjektív jóllét és igazságosság fontosságát, mint 
amelyek a megfeleló színvonalú élet nélkülözhetetlen elemei. Ezekhez képest viszont csak marginális jelentőségúnek ítéli a jövedelmi szintet, a társas létet, vagy boldogságot. Mivel a boldogságnak hedonikus és szociális értéke van, a legtöbb esetben más alapokon nyugszik, mint az emberi fejlődés vagy igazságosság. Ryff és Singer (2001) szintén az emberi fejlődés szakirodalmára alapozva a pszichés jóllét univerzális modelljét állította fel. Ryff szerint a pszichés múködést az önelfogadás, a személyes fejlődés, az életcélok, a másokhoz való pozitív kapcsolódás, a környezet megfeleló kezelése és az autonómia mentén kell értelmeznünk. Azok a kutatók, akik ezeket a célokat túzik ki vizsgálatuk elsődleges tárgyaként, figyelembe veszik az egyéni különbségeket és fejlődési változásokat a szubjektív jóllét szempontjából, s azt állítják, hogy a szubjektív jóllétet befolyásoló tényezók kultúránként különböznek, hiszen a kiemelkedố szükségletek és értékek kultúránként másképp alakulnak. Ezeket a kulturális sajátosságokat igazolta tulajdonképpen Diener és Diener (1995), akik vizsgálatukban kimutatták, hogy a barátokkal és a családdal való elégedettség kovariál az élettel való elégedettséggel, s ezek a korrelációk szignifikánsan változtak különbözó nemzetek esetében. A társadalom individualizáltságának mértéke pozitív korrelációban állt a baráti kapcsolattal és az élettel való elégedettséggel, jelezve, hogy a baráti kapcsolattal való elégedettség kevéssé szoros korrelációt mutat kollektivista társadalmakban az élettel való elégedettséggel. Ugyanakkor - ami a szerzók számára meglepó volt - a családi kapcsolatokkal való elégedettség és az élettel való elégedettség nem bizonyult erôsebbnek a kollektivista, mint az individualista társadalmakban.

Ráadásul az olyan kutatások száma valóban elenyészó, amelyek azt elemzik, hogy a serdülók körében pontosan mely tényezók azok, amelyek leginkább befolyásolják a szubjektív jóllétet, különös tekintettel a közeli kapcsolatok szerepére. Meehan (1999) a társas támasz, az észlelt kontroll és a napi események szubjektív jóllétre gyakorolt hatását elemezte serdülók körében. Négy hónapos idóeltéréssel vizsgálta a szubjektív jóllétre ható tényezóket. Nézete szerint a szubjektív jóllét alapvetôen Pozitív Jóllétból (boldogság, önértékelés, élettel való elégedettség, életerố) és Negatív Jóllétból (depresszió, düh, feszültség, zavartság és kimerültség) tevődik össze. Eredményei alapján a társas támogatottság és az észlelt kontroll pozitív hatással volt a Pozitív Jóllét alakulására. A viták gyakorisága ugyanakkor mind a Pozitív, mind a Negatív Jóllétre hatást fejtett ki. Sastre és Ferriere (2000) arra keresték a választ, hogy 12-19 évesek körében a serdülók szubjektív jóllétét milyen mértékben befolyásolja, ha a család szerkezetében változások következnek be. Vizsgálatuk érdekessége, hogy nevelóotthoni és családban felnövekvô serdülóket vontak be 
a vizsgálatba. Eredményeik szerint a két csoport között számottevố eltérés mutatkozott. A fiatalok élettel való elégedettségére közvetlen hatást fejtett ki a nevelóotthoni elhelyezés, közvetve pedig a családi élettel való elégedettség és személyes fejlődés gyakorolt befolyást.

Több olyan vizsgálat is ismert, ami azt bizonyítja, hogy a családban megtapasztalt igazságosság milyen fontos közvetítô szerepet játszik az igazságos világgal kapcsolatos nézetek formálódásában (Sallay és Dalbert 2004). Arra vonatkozóan is folyt egy kutatás (Sallay 2005), hogy a barátságban - mint a serdülók életében jelentős interperszonális kapcsolatban - az átélt igazságosság miképp múködik ebben közre. Az igazságos világba vetett hit alakulásában tehát mintegy elôzménynek tekinthetók a legfontosabb személyes kapcsolatokban átélt méltányos viselkedések. Épp ezért az itt bemutatásra kerüló vizsgálat a közeli kapcsolatokban - a családban és a barátságban - átélt igazságosság szerepét kívánja feltárni a szubjektív jóllét alakulására az igazságos világba vetett hit mellett. Mivel a családon kívül a közeli barátságok jelentik a fiataloknál a legfontosabb interperszonális kapcsolatot, ezért valószínú, hogy abban az esetben, ha a fiatalok méltányosságot, igazságosságot tapasztalnak baráti kapcsolatukban, ez mindenképp közrejátszik a szubjektív jóllétük kedvezó alakulásában. Minél inkább méltányosnak vélik családi légkörüket és baráti kapcsolatukat, annál inkább megerôsödik az igazságos világba vetett hit (Sallay 2005), s ez annál kedvezóbb hatást fejt ki a szubjektív jóllét komponenseire. Ez az összefüggést mutatja be az 1. ábra.

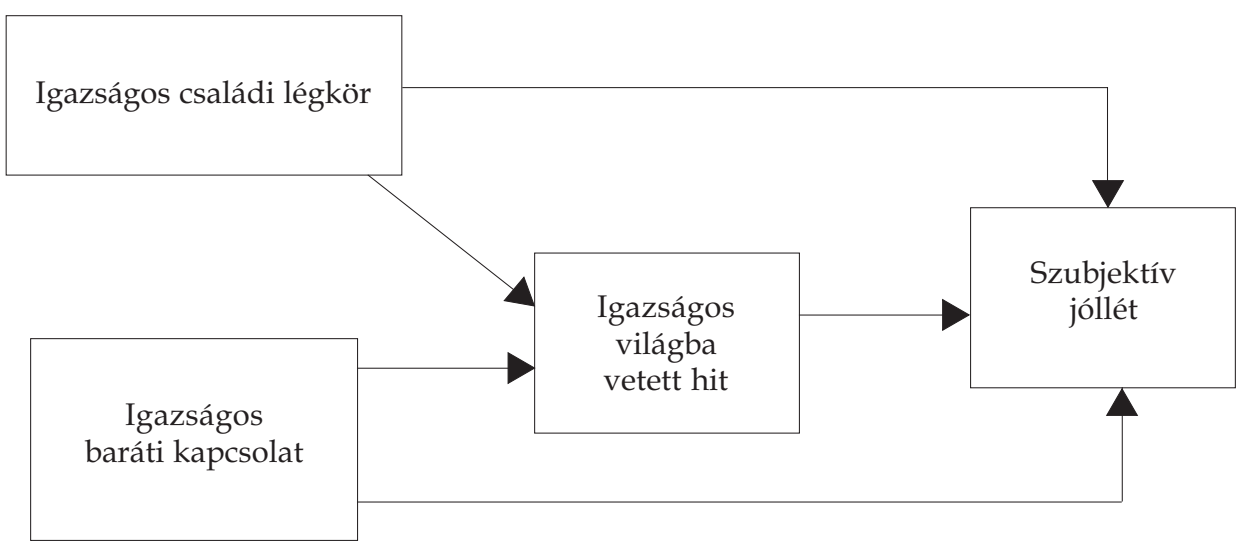

1. ábra. Az interperszonális kapcsolatokban átélt igazságosság, az igazságos világba vetett hit és a szubjektív jóllét kapcsolata 
A hipotéziseket is az elméleti modellel összhangban fogalmaztuk meg. Ennek megfelelóen feltételeztük, hogy (1) az igazságos családi légkör és a méltányos barátság közvetlenül járulnak hozzá az igazságos világba vetett hit alakulásához, (2) és az igazságos világba vetett hit egy közvetítô szerepet tölt be az interperszonális kapcsolatokban megtapasztalt méltányosság, igazságosság és a szubjektív jóllét között. Ugyanakkor az is várható, hogy (3) az interperszonális kapcsolatokban átélt igazságosság a szubjektív jóllét komponenseire eltéróen hat, valamint (4) elsósorban a személyes, s nem pedig az általános igazságos világba vetett hit az, ami közvetlen hatást gyakorol a szubjektív jóllétre. (5) Nemi különbségeket a korábbi vizsgálatoknak megfelelóen (l. Grob és mtsai 2001) - csupán a szubjektív jóllét komponensei közül a személyes problémáknál, a szomatikus tüneteknél, az önértékelésben és a depresszív hangulatnál várunk.

\section{MÓDSZEREK}

\section{Vizsgálati személyek}

2003-ban egy nagyobb felmérést végeztünk, melyben 217 fố vett részt $\left(\mathrm{N}_{\text {fiú }}=96, \mathrm{~N}_{\text {lány }}=121\right.$; átlagéletkor: 18,2 év). A személyek közül 191 fó nevelkedett teljes családban, 26 pedig elvált szülő́k gyermekeként. Vizsgálati mintánk az ország 14 különbözô megyéjéból származott. Az adatfelvételre egyetemi elôadások után került sor.

\section{Alkalmazott eljárások}

A szubjektív jóllétet a „Berni szubjektív jóllét kérdôiv" magyar változatával (Grob 1995) mértük fel. A kérdóív sikeres adaptálása már korábban megtörtént (Sallay 2004). A mérôeszköz a következó dimenziókat tartalmazza (zárójelben közöljük a megbízhatóság mértékét kifejezó $\alpha$-értékeket): az élettel szembeni pozitív attitúd (8 állítás, $\alpha=.78$; pl. „A jövóm jónak néz ki."), személyes problémák (8 állítás, $\alpha=.71$; pl. " Hányszor fordult eló az elmúlt hetekben, hogy aggódtál, mert problémáid voltak más emberekkel?"), szomatikus tünetek és reakciók (8 állítás, $\alpha=.76$; pl. „Előfordult az elmúlt hetekben, hogy szokatlanul fáradtnak érezted magadat?"), önértékelés (4 állítás, $\alpha=.69$; pl. „ Képes vagyok legalább olyan jól elvégezni a dolgokat, mint a legtöbb ember."), depresszív hangulat (5 állítás, $\alpha=.70$; pl. ", Már semmit sem szeretek csinálni."), az élet örömei (5 állítás, $\alpha=.81$; pl. "Örültél-e az elmúlt hetekben azért, mert sikerült 
elérned valamit?"). Az igazságos világba vetett hit két dimenzióját mértük. Az általános igazságos világba vetett hitet az "Általános igazságos világba vetett hit" skálával (6 állítás, $\alpha=.77$; Dalbert és mtsai 1987; pl. „Úgy vélem, hogy a világban általában igazságosan történnek a dolgok."), valamint a személyes igazságos világba vetett hitet a "Személyes igazságos világba vetett hit" skálával (7 állítás, $\alpha=$.86; Dalbert, 1999; pl. "Az életem nagyjából igazságosan zajlik."). Az igazságos családi légkörról szerzett tapasztalatokat az "Igazságos családi légkör" skála tárta fel $(\alpha=.79$; Goch és Dalbert 1998; pl. „Nálunk otthon igazságosan történtek a dolgok."). Az igazságos baráti kapcsolatról szerzett tapasztalatokat az "Igazságos baráti kapcsolat" skála segítségével vizsgáltuk (5 állítás, $\alpha=.74$; Sallay 2005; pl. „Baráti körömben a fontos kérdések eldöntésekor mindenki az igazságosságra törekszik."). A személyek minden egyes állításra egy hatfokú, Likert-típusú skálán válaszoltak (1: egyáltalán nem értek egyet, 6: teljes mértékben egyetértek). A demográfiai adatokra a kérdőív végén kérdeztünk rá.

\section{EREDMÉNYEK}

\section{Átlagos különbségek}

Egy szempontos varianciaanalízissel megvizsgáltuk azt, hogy a nemek között mutatkozik-e szignifikáns eltérés az igazságossággal kapcsolatos nézetek, valamint a szubjektív jóllét dimenziói között. Az igazságossággal kapcsolatos dimenzióknál nem észleltünk szignifikáns különbségeket, ugyanakkor a szubjektív jóllét tekintetében három szignifikáns eltérés is jelentkezett. A lányok szignifikánsan több személyes problémát említettek $\left(\mathrm{F}_{(1,214)}=6.226 ; p \leq .013, M=2.66, S D=.68\right)$, mint a fiúk $(M=2.43$, $S D=.66)$. Több szomatikus panaszuk is volt $\left(\mathrm{F}_{(1,216)}=23.445 ; p \leq .000, M\right.$ $=2.14, S D=.73)$, mint a fiúknak $(M=1.72, S D \stackrel{.48}{=}$, s önértékelésük is alacsonyabbnak bizonyult $\left(\mathrm{F}_{(1,216)}=6.456 ; p \leq .012, M_{\text {lány }}=3.57, S D_{\text {lány }}=\right.$ $\left..70 ; M_{\text {fiú }}=3.82, S D_{\text {fiú }}=.70\right)$.

\section{Az igazságos világba vetett hit, a családi igazságos légkör, a baráti kapcsolat igazságossága és a szubjektív jóllét összefüggései}

Annak érdekében, hogy feltárjuk az igazságos családi légkör és igazságos barátság, mint szocializációs hátterekben megélt méltányosság, valamint az igazságos világba vetett hit hozzájárulását a szubjektív jóllét- 
1. táblázat. Az igazságos világba vetett hit, igazságos családi légkör, igazságos barátság és szubjektív jóllét átlagai (M), szórásai (SD) és korrelációi

\begin{tabular}{|c|c|c|c|c|c|c|c|c|c|c|c|c|}
\hline & $M$ & SD & 1 & 2 & 3 & 4 & 5 & 6 & 7 & 8 & 9 & 10 \\
\hline \multicolumn{13}{|l|}{ 1. Nemek } \\
\hline 2. Általános igazságos világba vetett hit & 3.39 & .89 & -.06 & & & & & & & & & \\
\hline 3. Személyes igazságos világba vetett hit & 4.01 & .82 & $.17^{*}$ & $.54^{* *}$ & & & & & & & & \\
\hline 4. Igazságos családi légkör & 4.43 & .90 & $.31^{*}$ & $.30^{* *}$ & $.59^{* *}$ & & & & & & & \\
\hline 5. Igazságos barátság & 4.13 & .82 & $-.17^{*}$ & $.46^{* *}$ & $.49^{* *}$ & $.55^{* *}$ & & & & & & \\
\hline 6. Élettel szembeni pozitív attitúd & 3.64 & .60 & .05 & $.19^{* *}$ & $.35^{* *}$ & $.28^{* *}$ & $.30^{* *}$ & & & & & \\
\hline 7. Személyes problémák & 2.56 & .68 & -.08 & .07 & $-.14^{*}$ & $-.16^{*}$ & -.03 & $-.32 * *$ & & & & \\
\hline 8. Önértékelés & 1.96 & .67 & .09 & .08 & $.22 * *$ & $.24^{* *}$ & $.17^{*}$ & $.57^{* *}$ & $-.38^{* *}$ & & & \\
\hline 9. Depresszív hangulat & 3.68 & .71 & .00 & -.13 & $-.30^{* *}$ & $-.29 * *$ & $-.22 * *$ & $-.48^{* *}$ & $.27^{* *}$ & $-.51^{* *}$ & & \\
\hline 10. Szomatikus panaszok & 2.04 & .65 & -.05 & -.05 & $-.22^{* *}$ & $-.23^{* *}$ & -.09 & $-.30 * *$ & $.49 * *$ & $-.38^{* *}$ & $.45^{\star *}$ & \\
\hline 11. Az élet örömei & 3.47 & .69 & .08 & .09 & $.19^{* *}$ & $.17^{*}$ & $.16^{*}$ & $.54^{* *}$ & $-.22^{* *}$ & $.56^{* *}$ & $-.24^{* *}$ & $-.24^{* *}$ \\
\hline
\end{tabular}

Megjegyzés: ${ }^{*} \mathrm{p} \leq .05 ;{ }^{* *} \mathrm{p} \leq .01$ 
hez, többváltozós regresszióelemzést hajtottunk végre külön-külön minden egyes szubjektív jóllét dimenzióra nézve. Ehhez első lépésként a lehetséges összefüggéseket a változók között korrelációs elemzéssel vizsgáltuk (1. táblázat), ami megmutatta, hogy szoros összefüggések állnak fenn az átélt kapcsolatok (igazságos családi légkör és baráti kapcsolat), igazságos világ dimenziók, valamint szubjektív jóllét dimenziók között.

A változókat „stepwise” módszerrel léptettük be a blokkokon belül; a szignifikancia-szintet $p<.05$-nél rögzítettük. Az elsó blokkba a nemek ( 0 = férfi; 1 = nô) változója („,dummy” változó) került, a második blokkba az igazságos világba vetett hit dimenziói és az igazságos családi légkör, illetve barátság, a harmadikba pedig a kétoldalú interakciók a "dummy" változó és az igazságos világba vetett hit dimenziói, valamint az igazságos családi légkör, illetve barátság között. Azokat az interakciókat, melyek nem voltak szignifikánsak, s változókat, melyek nem voltak részei a szignifikáns interakcióknak, vagy nem mutattak szignifikáns fó hatást, töröltük a regresszióból. Az elfogadott modelleket a 2. táblázat szemlélteti.

Az eredmények szerint az élettel szembeni pozitív attitúdön végzett lineáris regresszióelemzés a személyes igazságos világba vetett hit és az igazságos barátság szignifikáns hatását mutatta ki, ami a teljes variancia 14\%-át magyarázta. Minél inkább hittek a megkérdezettek a személyes igazságos világban, s minél inkább igazságosnak élték meg baráti kapcsolatukat, annál pozitívabban viszonyultak az élethez, ahogyan ezt a 2. ábra mutatja.

A nemek és a személyes igazságos világba vetett hit a személyes problémák esetében bizonyult szignifikánsnak, s együttesen a variancia 5\%át magyarázta. Minél inkább hisznek a megkérdezettek a személyes igazságos világban, s különösen, ha fiúk, annál kevesebb személyes problémáról számoltak be (3. ábra).

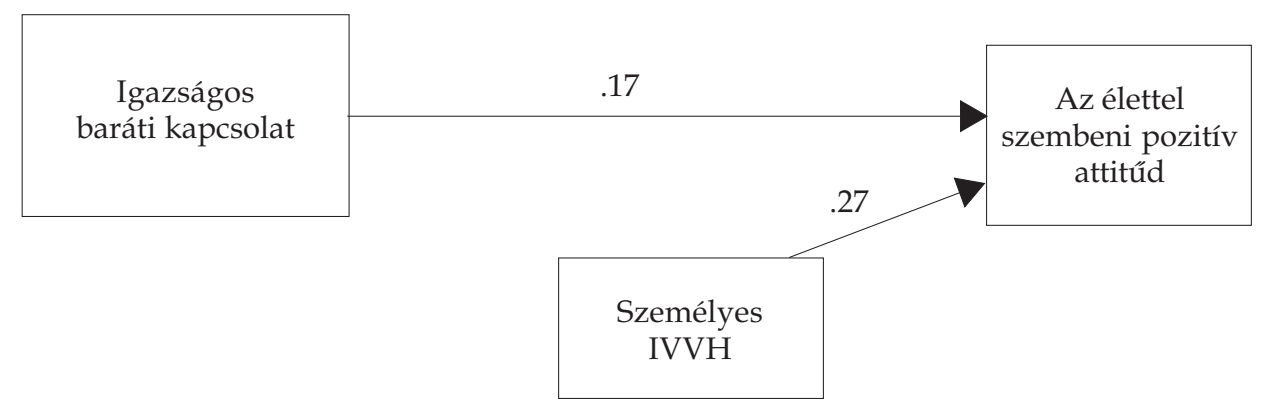

2. ábra. Az igazságos baráti kapcsolat és a személyes

igazságos világba vetett hit (IVVH) hatásai az élettel szembeni pozitív attitúdre

(a feltüntetett számok a beta-értékeket jelzik) 
2. táblázat. A szubjektív jóllét regressziója az igazságos világba vetett hitre, igazságos családi légkörre, igazságos baráti kapcsolatra és nemekre (elfogadott modellek; $\mathrm{p}<.05$ )

\begin{tabular}{lcrrrr}
\hline Prediktor & $R$ & $R^{2}$ & $b$ & $T$ & $p$ \\
\hline Az élettel szembeni pozitív attitúd $\left(F_{\text {total }}=17.433 ; d f=2 / 214 ; p<.000\right)$ & & \\
Személyes igazságos világba vetett hit & .35 & $.12_{\mathrm{c}}$ & .19 & 3.67 & .000 \\
Igazságos baráti kapcsolat & .38 & $.14 \mathrm{a}$ & .12 & 2.25 & .026 \\
(Konstans) & & & 2.37 & &
\end{tabular}

Személyes problémák $\left(F_{\text {total }}=5.1103 ; d f=2 / 212 ; p=.007\right)$

$\begin{array}{llllll}\text { Nemek } & .16 & .03 & .22 & 2.44 & .015\end{array}$

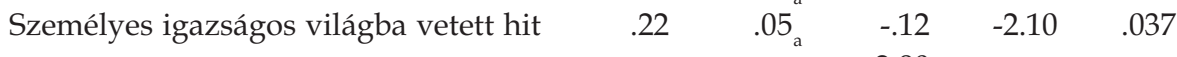

Szomatikus panaszok és reakciók $\left(F_{\text {total }}=17.543 ; d f=2 / 214 ; p<.000\right)$

$\begin{array}{lllrrr}\text { Nemek } & .31 & .10_{c} & .41 & 4.87 & .000 \\ \text { Személyes igazságos világba vetett hit } & .38 & .14_{c} & -.17 & -3.41 & .001\end{array}$

Önértékelés $\left(F_{\text {total }}=9.808 ; d f=2 / 211 ; p<.000\right)$

$\begin{array}{lllllll}\text { Nemek } & .18 & .03_{\mathrm{b}} & -.24 & -2.51 & .013\end{array}$

$\begin{array}{llllll}\text { Igazságos családi légkör } & .29 & .09 & .19 & 3.53 & .001\end{array}$

Depresszív hangulat $\left(F_{\text {total }}=13.191 ; d f=2 / 210 ; p=.000\right)$

$\begin{array}{llllll}\text { Személyes igazságos világba vetett hit } & .31 & .10 & -.17 & -2.65 & .009\end{array}$

$\begin{array}{llllll}\text { Igazságos családi légkör } & .34 & .11_{a}^{c} & -.12 & -2.00 & .046\end{array}$

Az élet örömei $\left(F_{\text {total }}=7.751 ; d f=1 / 214 ; p<.006\right)$

$\begin{array}{lllllll}\text { Személyes igazságos világba vetett hit } & .19 & .04_{\mathrm{b}} & .16 & 2.78 & .006\end{array}$

Általános igazságos világba vetett hit $\left(F_{\text {total }}=7.751 ; d f=1 / 213 ; p<.000\right)$

$\begin{array}{llrrrr}\text { Igazságos baráti kapcsolat } & .46 & .21_{c} & .50 & 7.56 & .000\end{array}$

Személyes igazságos világba vetett hit $\left(F_{\text {total }}=7.751 ; d f=1 / 213 ; p<.000\right)$

$\begin{array}{llllll}\text { Igazságos családi légkör } & .59 & .35 & .43 & 7.08 & .000\end{array}$

$\begin{array}{lllllll}\text { Igazságos baráti kapcsolat } & .62 & .39^{c} & .24 & 3.61 & .000\end{array}$

Megjegyzés: a $p<.05, \mathrm{~b} p<.01, \mathrm{c} p<.001$ 


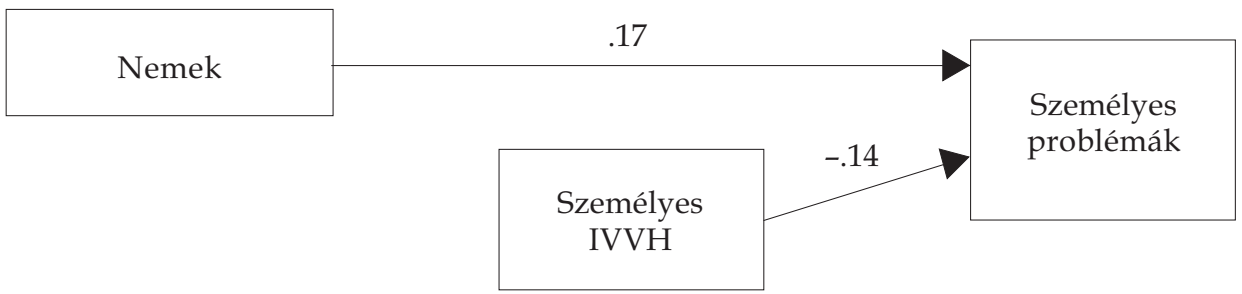

3. ábra. A nemek és a személyes igazságos világba vetett hit (IVVH) hatása a személyes problémákra (a feltüntetett számok a beta-értékeket jelzik)

A nemek és a személyes igazságos világba vetett hit a szomatikus panaszokra gyakorolt hatást, együttesen a varancia $14 \%$-át magyarázva. Minél erősebb volt a személyes igazságos világba vetett hit, annál kevesebb panaszról adtak számot, illetve a lányok több tünetról panaszkodtak (4. ábra).

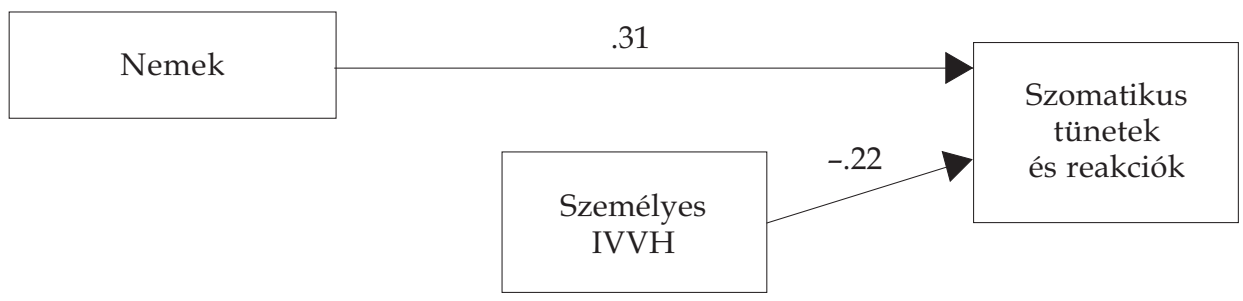

4. ábra. A nemek és a személyes igazságos világba vetett hit (IVVH) hatása a szomatikus tünetekre és reakciókra (a feltüntetett számok a beta-értékeket jelzik)

Az önértékelést részint a nemek, részint az igazságos családi légkör befolyásolta. Ez a két változó a variancia $9 \%$-át magyarázta együtt. Minél igazságosabbnak észlelték a személyek a családi légkört, annál magasabb volt önértékelésük, elsósorban pedig akkor, ha fiúkról volt szó (5. ábra).

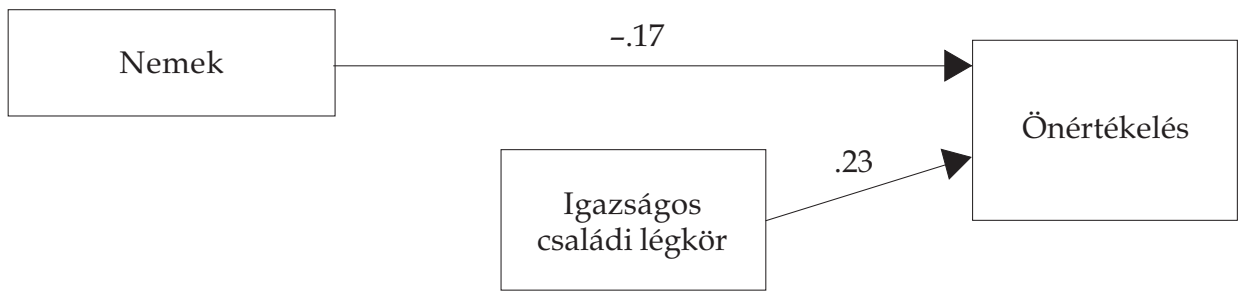

5. ábra. A nemek és az igazságos családi légkör hatása az önértékelésre

(a feltüntetett számok a beta-értékeket jelzik) 
A depresszív hangulatot a személyes igazságos világba vetett hit és az igazságos családi légkör valószínúsítette, együttesen a varanciának 11\%át magyarázva. Minél inkább hittek a válaszadók a személyes igazságos világban, és családi légkörüket minél méltányosabbnak élték meg, annál kevésbé hajlottak a depresszív hangulatra (6. ábra).

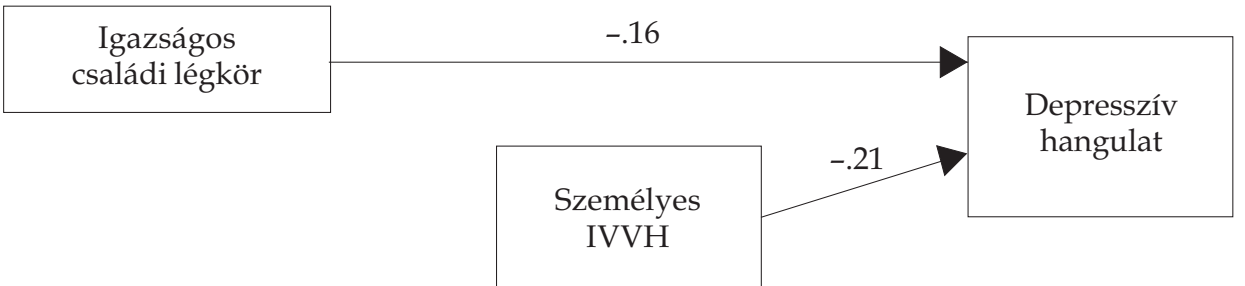

6. ábra. Az igazságos családi légkör és a személyes igazságos világba vetett hit (IVVH) hatása a depresszív hangulatra (a feltüntetett számok a beta-értékeket jelzik)

Az élet örömeire a személyes igazságos világba vetett hit gyakorolt egyedül fó hatást, a varianciának 4\%-át magyarázva (7. ábra).

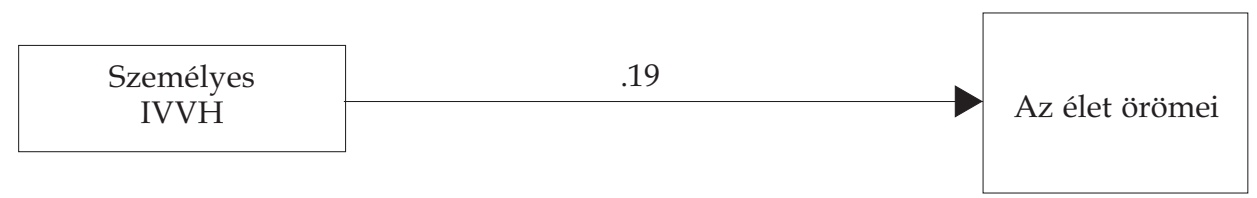

7. ábra. A személyes igazságos világba vetett hit (IVVH) hatása az élet örömeire (a feltüntetett számok a beta-értékeket jelzik)

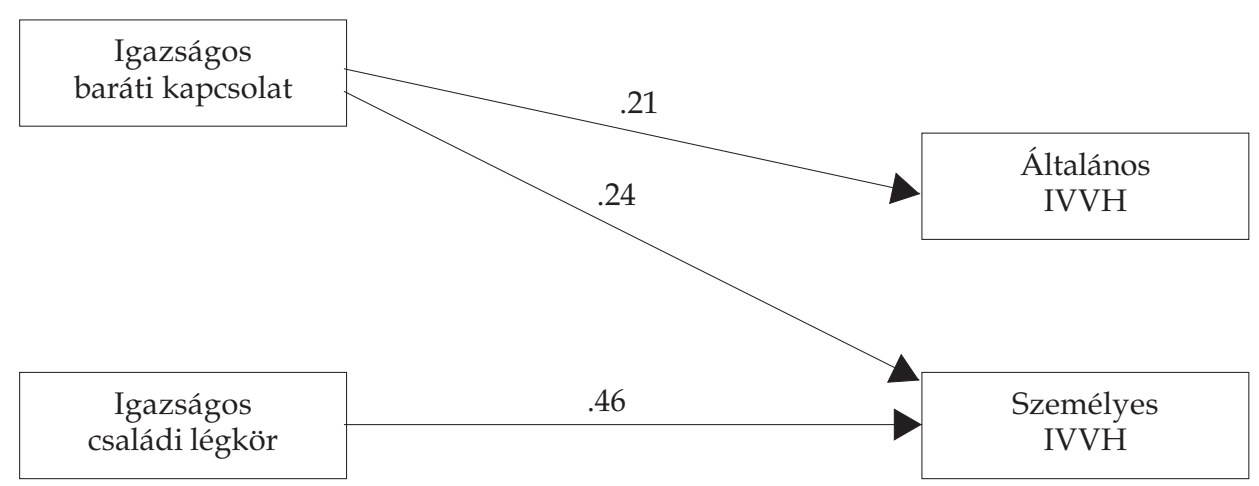

8. ábra. Az igazságos baráti kapcsolat és az igazságos családi légkör hatásai az általános és személyes igazságos világba vetett hit (IVVH) alakulására (a feltüntetett számok a beta-értékeket jelzik) 
Az általános igazságos világba vetett hitet az igazságos baráti kapcsolat valószínúsítette, a varianciának $21 \%$-át magyarázva. Végül a személyes igazságos világba vetett hitet mind az igazságos barátság, mind pedig az igazságos családi légkör befolyásolta. A két változó együttesen 39\%-os magyarázó erővel rendelkezett. Minél inkább igazságosnak percipiálták a megkérdezettek a családi légkörüket és baráti kapcsolatukat, annál erősebben hittek a személyes igazságos világban. A fenti összefüggések a 8. ábrán láthatók.

\section{KÖVETKEZTETÉSEK}

Vizsgálatunkban arra kerestünk választ, hogy az igazságos világba vetett hit és a családban, valamint közeli baráti kapcsolatban átélt igazságosság mennyiben járul hozzá a serdülók szubjektív jóllétéhez. Rá kívántunk mutatni arra, hogy az interperszonális kapcsolatokban átélt igazságosság tulajdonképpen nélkülözhetetlen ahhoz, hogy a stabil igazságos világba vetett hit kialakuljon, ami pedig a mentális egészség megőrzéséhez alapvetóen fontos.

A nemek között különbségek - elvárásainkkal összhangban - a szubjektív jóllétnek csupán néhány dimenziójában jelentkeztek. A lányok voltak azok, akik több személyes problémáról számoltak be, több szomatikus panaszuk jelentkezett, és önértékelésük sem volt olyan magas, mint a fiúké. Ezek az eredmények más kutatásokban tapasztaltakkal teljes összhangot mutatnak (pl. Grob 1998; Grob és mtsai 2001).

A többváltozós lineáris regressziós elemzések révén az igazságossággal kapcsolatos nézetek, valamint a közeli kapcsolatokban átélt igazságosság szerepét tártuk fel a szubjektív jóllét alakulásában. Eredményeink azt mutatták, hogy mind a családi igazságos légkörnek, mind pedig a barátságokban megtapasztalt igazságosságnak jelentős szerepe van az igazságos világba vetett hit formálódásában. Míg azonban a baráti kapcsolatokban átélt igazságosság mind az általános, mind a személyes igazságos világba vetett hit alakulásában közrejátszik, a családi igazságos légkörnek csak a személyes igazságos világba vetett hit fejlődésében van szerepe. Más vizsgálatok eredményei (1. Dalbert és Radant 2004) is azt a feltevést tûnnek igazolni, miszerint a fejlődési folyamat során a késó serdülő- és fiatal felnôttkorra az általános igazságos világba vetett hit alakulását már inkább a családon kívüli tényezôk befolyásolják, és hangsúlyossá válik az, hogy mi történik más emberekkel a világban. Ehhez természetesen megfelelő kognitív fejlettségi szintre, absztrakciós készségekre is szükség van, ami gyerekkorban még nem áll rendelkezésre. Ezzel szem- 
ben a személyes igazságos világba vetett hit más fejlódési útvonalat követ - a személyes tapasztalatok alapján ez az, ami elóször kialakul, s a kognitív fejlódéssel párhuzamosan differenciálódik az általános igazságos világba vetett hit (Dalbert 2001).

Az a feltevésünk is helytállónak bizonyult, mely szerint az interperszonális kapcsolatokban átélt igazságosság a szubjektív jóllét komponenseire eltérően hat. A baráti kapcsolatokban átélt igazságosság kizárólag egyetlen szubjektív jóllét komponenssel, az élettel szembeni pozitív attitúdökkel állt szignifikáns kapcsolatban. Ez arra utal, hogy amennyiben méltányosságot tapasztal a serdülő baráti kapcsolatában, ez hozzájárulhat ahhoz, hogy kedvezó attitúdökkel forduljon általában az élethez, mivel ez a tapasztalat azt mutatja számára, hogy az igazságos világba vetett hit egyik funkciója - az, hogy bízhat abban, hogy mások méltányosan fognak vele bánni - beigazolódik. Ebben a vizsgálatban a baráti kapcsolat egyéb sajátosságait nem elemeztük, csupán azt, hogy a személy mennyire észleli a méltányosságot az adott kapcsolatban. Berndt (1982) serdülôkori barátságok hatását és jellemzóit összefoglaló tanulmányában azt hangsúlyozza, hogy a serdülókori barátságok jellemzője a beszélgetések intimitása, az egymástól való kölcsönös ismeretek, egymás szükségleteinek és kívánságainak teljesítése. Amennyiben a kölcsönösség nem valósul meg, és az intimitás nem megfeleló, valószínúleg nem fogja a serdüló baráti kapcsolatában a méltányosságot észlelni, s ez kedvezótlenül hathat mind az igazságos világba vetett hitre, mind pedig az általános, élettel szembeni attitúdjére, mint a szubjektív jóllét egyik komponensére. Ennek közelebbi vizsgálata már önmagában is izgalmas kérdés, azonban további taglalása túlmutat a jelen vizsgálat keretein.

A családi igazságos légkörnél két komponens esetében figyeltünk meg szignifikáns hatást: minél igazságosabbnak értékelték a serdülők saját családi légkörüket, annál kevésbé tartották magukat lehangoltnak, viszont önértékelésük annál magasabbnak bizonyult. Ez azt jelenti, hogy a család a megfelelố pozitív értékeléseivel és támogatásával valószínúleg nagyban elősegíti azt, hogy a serdülők jó hangulatban legyenek és saját magukról is megfeleló értékelést alakítsanak ki.

Eredményeink alapján az is nyilvánvaló, hogy elsôsorban a személyes igazságos világba vetett hit az, ami a mediátor szerepét tölti be a személyes kapcsolatokban átélt igazságosság, valamint a szubjektív jóllét komponensei között, s ezt az bizonyítja, hogy a hat szubjektív jóllét komponens közül öt esetben szignifikáns hatásokra sikerült rámutatnunk. Minél inkább hittek a serdülők a saját sorsukat érintố igazságos világban, annál pozitívabb volt az élettel szembeni attitúdjük, annál kevesebb személyes problémáról és szomatikus panaszról számoltak be, annál kevés- 
bé érezték magukat lehangoltnak és élvezték az élet örömeit. Vizsgálatukban Dzuka és Dalbert (2002) hasonló eredményekról számoltak be.

Ezek az eredmények összhangban állnak mindazokkal a kutatásokkal, melyek az igazságos világba vetett hit szerepét bizonyítják a mentális egészség megórzésében (1. Dalbert 2001), s egyben arra is rámutatnak, hogy a családnak és baráti kapcsolatnak, illetve az itt percipiált igazságosságnak miképp „gyưrúzik át” a hatása a szubjektív jóllétre. A vizsgálatnak természetesen megvannak a korlátai is: feltételezhető, hogy e két kapcsolati formán kívül más közegekben - pl. iskolában, osztályokban és tanárral való kapcsolatban - az átélt méltányosság/méltánytalanság szintén közrejátszik mind az igazságos világba vetett hit, mind a szubjektív jóllét alakulásában. Az iskolai hatásokat illetôen nemrégiben Dalbert és Maes (2002) mutattak rá arra, hogy az észlelt méltányosság nemenként változhat is; vizsgálatuk eredményei szerint a lányok tanáraikat többnyire igazságosabbnak látják, mint a fiúk. Emellett azok, akik jó jegyeket kapnak, s személyes igazságos világba vetett hitük erôsebb, igazságosabbnak látják tanáraikat, mint azok, akik rossz tanulók és kevésbé hisznek a személyes igazságos világban.

A fenti érvelés nem hagy kétséget afelól, hogy további vizsgálatok szükségesek annak feltárásához, hogy a különbözó szocializációs közegekben, interperszonális kapcsolatokban percipiált igazságosság, méltányosság milyen súllyal játszik szerepet mind a személyes igazságosság-motívum formálódásában, mind pedig ennek szubjektív jóllétre, mentális egészségre gyakorolt hatásában.

\section{Irodalom}

Agrawal, M., Dalal, A. K. (1993): Beliefs about the world and recovery from myocardial infarction. Journal of Social Psychology, 133: 385-394.

Benson, D. E., Ritter, C. (1990): Belief in a just world, job loss and depression. Sociological Focus, 23: 49-63.

Berndt, T. J. (1982): The features and effects of friendship in early adolescence. Child Development, 53 (6): 1447-1460.

Bradburn, A. (1969): The Structure of Psychological Well-being. Chicago, Aldine.

Burke, R. J. (1985): Beliefs and fears underlying Type A behavior. Journal of General Psychology, 112: 133-145.

Cantril, H. (1965): The pattern of human concern. Rutgers University Press, New Brunswick, NJ.

Dalbert, C. (1999): The world is more just for me than generally: About the personal belief in a just world scale's validity. Social Justice Research, 12: 79-98.

Dalbert, C. (2001): The Justice Motive as a Personal Resource. Dealing with Challenges and Critical Life Events. New York, Kluwer Academic/Plenum Pulishers.

Dalbert, C., Maes, J. (2002): Belief in a just world as a personal resource in school. In Ross, 
M., Miller, D. T. (eds): The Justice Motive in Everyday Life. Cambridge University Press, Cambridge, 365-381.

Dalbert, C., Montada, L., Schmitt, M. (1987): Glaube an eine gerechte Welt als Motiv: Validierungskorrelate zweier Skalen. Psychologische Beitrage, 29: 596-615.

Dalbert, C., Radant, M. (2004): Parenting and young adolescents' belief in a just world. In Dalbert, C., Sallay H. (eds): The Justice Motive in Adolescence and Young Adulthood: Origins and Consequences. Routledge, London, 11-26.

Diener, E. (1984): Subjective well-being. Psychological Bulletin, 95: 542-575.

Diener, E., Diener, M. (1995): Cross-cultural correlates of life satisfaction and self-esteem. Journal of Personality and Social Psychology, 68: 653-663.

Dzuka, J., Dalbert, C. (2002): Mental health and personality of Slovak unemployed adolescents. About the beliefs in a just world's impact. Journal of Applied Social Psychology, 32: 732-757.

Fend, H. (1990): Vom Kind zum Jugendlichen. Huber, Bern.

Furnham, A., Proctor, E. (1989): Beliefs in a just world. Review and critique of the individual difference literature. British Journal of Social Psychology, 28: 365-384.

Goch, I., Dalbert, C. (1998, June): Socialisation Processes within the Family and the Belief in a Just World (poster). 6th Biennial Conference of the European Association for Research on Adolescence, Budapest.

Grob, A. (1995): Subjective well-being and significant life-events across the life-span. Swiss Journal of Psychology, 54: 3-18.

Grob, A. (1998): Adolescents' subjective well-being in fourteen cultural contexts. In Nurmi, J.-E. (ed.): Adolescents, Cultures and Conflicts. Growing up in Contemporary Europe. Garland Publishing, New York, 21-43.

Grob, A., Little, T. D., Wanner, B., Wearing, A. J., Euronet (1996): Adolescents' well-being and perceived control across 14 sociocultural contexts. Journal of Personality and Social Psychology, 71: 785-795.

Grob, A., Lemler-Lauerbach, A., Rietz, C., Weisheit, W. (2001): Subjektives Wohlbefinden von drei Generationen derselben Familie. - Paper presented at $6^{\text {th }}$ Workshop for Differential, and Personality Psychology and Psychological Diagnostics of the German Psychological Society, Leipzig, Germany.

Katja, R., Paivi, A. K., Marja-Terttu, T., Pekka, L. (2002): Relationships among adolescent subjective well-being, health behaviour, and school satisfaction. Journal of School Health, 72: 243-249.

Kiecolt-Glaser, J. K., Williams, D. A. (1987): Self-blame, compliance, and distress among burn patients. Journal of Personality and Social Psychology, 53: 187-193.

Konu, A. I., Lintonen, T. P., Rimpela, M. K. (2002): Factors associated with schoolchildren's general subjective well-being. Health Education Research, 17:155-165.

Lane, J. (2000): A scientific approach for developing and testing a student's job-career plan before $11^{\text {th }}$ grade. Education, 120: 605-613.

Lerner, M. J. (1987): Integrating societal and psychological rules of entitlement: The basic task of each social actor and fundamental problem for the social sciences. Social Justice Research, 1: 107-125.

Lerner, M. J. (1998): The two forms of the "belief in a just world": Some thoughts on why and how people care about victims. In Montada, L., Lerner, M. J. (eds): Responses to Victimization and Belief in a Just World. Plenum, New York, 247-269. 
Lerner, M. J., Somers, D. G. (1992): Employee's reaction to an anticipated plant closure: The influence of positive illusions. In Montada, L., Filipp, S. H. (eds): Life crises and experiences of loss in adulthood. Erlbaum, Hillsdale, N.J., 229-254.

Lipkus, I. M., Dalbert, C., Siegler, I. C. (1996): The importance of distinguishing the belief in a just world for self versus others. Personality and Social Psychology Bulletin, 22: 666677.

Meehan, M. P. (1999): The structure of subjective well-being and its relationship to social support, perceived control, and life events in adolescence: A prospective analysis, Dissertation Abstracts International: Section B: The Sciences and Engineering, 60 (2B): 0837.

Rubin, Z., Peplau, A. (1973): Belief in a just world an reactions to another's lot: A study of participants in a national draft lottery. Journal of Social Issues, 29: 73-93.

Rubin, Z., Peplau, A. (1975): Who believes in a just world? Journal of Social Issues, 31: 6589.

Ryff, C. D., Singer, B. H. (2001): Emotions, social relationships, and health. Oxford University Press, New York.

Sallay, H. (2004): Entering the job market: belief in a just world, fairness and well-being of graduating students. In Dalbert, C., Sallay, H. (eds): The Justice Motive in Adolescence and Young Adulthood: Origins and Consequences. Routledge, London, 215-231.

Sallay, H. (2005): Az implicit igazságosság motíoum alakulása és hatásai: a szocializáció szerepe. Habilitációs értekezés, Debreceni Egyetem.

Sallay, H., Dalbert, C. (2004): The development of the belief in a just world: The impact of being raised in a one-parent or an intact family. In Dalbert, C., Sallay, H. (eds): The Justice Motive in Adolescence and Young Adulthood: Origins and Consequences. Routledge, London, 26-43.

Sastre, M. T. M., Ferriere, G. (2000): Family "decline" and the subjective well-being of adolescents. Social Indicators Research, 49: 69-82.

Schmitt, M., Maes, J. (2000): Vorschlag zur Vereinfachung des Beck-Depressions-Inventars (BDI). Diagnostica, 46: 38-46.

Taylor, S., Brown, J. (1988): Illusion and well-being: A social-psychological perspective on mental health. Psychological Bulletin, 103: 193-210.

\section{SALLAY, HEDVIG}

\section{ADOLESCENTS' SUBJECTIVE WELL-BEING: THE ROLE OF JUST WORLD BELIEFS AND PERCEIVED JUSTICE IN THE FAMILY AND FRIENDSHIP}

The "belief in a just world" hypothesis was formulated by Melvin Lerner. According to this belief, people think that people usually get what they deserve and deserve what they get in their lives. Several previous studies proved that the justice motive shows a close relation with mental health. Generally, the stronger this belief is, the more people are motivated to protect it and do their best in order to activate adaptive coping mechanisms when it is necessary. 
This study investigates adolescents' subjective well-being in order to explore the role of the justice motive and the experienced justice in the family and close friendship relationship in adolescents' mental health. Analysing the different components of subjective well-being (positive attitudes towards life; personal problems; somatic complaints and reactions; selfesteem; depressive mood; joy in life) the results unambiguously proved that the perceived justice in different socialising contexts, as well as the justice motive represent significant factors in maintaining mental health.

Keywords: adolescence, justice motive, subjective well-being, socialising contexts 